\title{
A RESPONSABILIDADE PATRIMONIAL DO ESTADO POR ATOS CRIMINOSOS DE TERCEIROS
}

\author{
MANOEL LAURO VOLKMER DE CASTILHO*
}

\section{SUMĀRIO}
A) INTRODUÇĀO
B) A PERSPECTIVA PENAL
1. O Crime
2. A Justiça
3. A relação delinqüente/vítima e a intervenção do Estado

C) A QUESTÃO DA RESPONSABILIDADE 1. O Princípio do resíduo

2. A nova maneira de pensar

3. A evolução do risco e o risco social

D) CONCLUSÃO

\footnotetext{
*Trabalho apresentado à Disciplina de Direito Administrativo do Curso de Pós-graduação do Setor de Ciências Jurídicas da UFPR.
} 


\section{A) INTRODUÇĀO}

Cuida-se de apresentar com o presente trabalho estudos sobre a possível responsabilidade patrimonial do Estado perante os cidadãos, por danos decorrentes de atos criminosos de terceiros.

Na primeira parte procura-se sumariar para efeito de compreensão dos limites do tema a noção de crime e as suas ramificações mais significativas consoante os respectivos objetos jurídicos penalmente tutelados.

Em seguida, acercando-se do núcleo da investigação pretende-se oferecer um apanhado sobre a pena, sua função (como elemento de reparação, castigo ou reabilitação), bem como, aí a novidade, extrair disso elementos para a fundamentação da responsabilidade patrimonial do Estado, cuja intervenção oficial e obrigatória na relação da dupla penal delinqüente/vítima faz então produzir potencialmente a legitimação passiva daquele na demanda civil reparatória do dano 'ex-delicto'.

$\mathrm{Na}$ segunda parte, completa-se o exame da responsabilidade residual decorrente do fato do Estado, através de elaboração teórica por discurso fundado em nova maneira de pensar tais questões. Ensaia-se, por fim, uma projeção da evolução da teoria do risco até o ponto extremo do risco social e, neste, o princípio da socialidade.

Rematam o texto as conclusões tiradas, em especial a que reconhece o recurso à jurisdição civil para satisfação material da reparação.

\section{B) A PERSPECTIVA PENAL}

\section{O CRIME}

Ademais das noções jurídico-penais e das questões técnicas de direito penal a noção de crime envolve sempre uma dimensão pouco explorada e apartada da preocupação ordinária dos estudiosos. Por uma certa perspectiva, todo o crime, em verdade, é antes de tudo uma conduta políticamente reacionária, egoista $\mathrm{e}$ socialmente desvaliosa. Porque ofende sempre um interesse ainda que remoto do Estado o crime é também atitude de oposição atípica no sentido de que repele o Estado como agente da vontade coletiva. 
Essa é a razão pela qual o Estado é logicamente em termos jurídico-penais sujeito passivo do crime, isto é, é, em sentido amplo e residual, ofendido pela conduta reprovada.

Assim, independente da grandeza das penas todos os crimes, lesando interesses individuais ou de grupos, detrimem interesse estatal e nessa perspectiva atacam o Estado perturbando-Ihe a tarefa própria e inconteste de cumprir o fim social de seus propósitos e proporcionar aos seus cidadãos o bem-estar e felicidade que ditaram a razão do próprio Estado.

Por conseqüência os crimes comuns, urbanos ou rurais, de atentado ao patrimônio dos cidadãos; aos costumes da sociedade organizada; à vida, etc. . . lesam também sempre e objetivamente uma preocupação oficial do Estado. No caso brasileiro, maiormente, posto que se funda toda a sua organização jurídica no princípio cardeal da propriedade particular de um modo geral cultuada também pelas democracias liberais ocidentais como índice paradigmático de valor de suas instituições. $O$ interesse do Estado é, aí, notável, como é fácil compreender vez que tal situação abriga a razão ideológica do seu ser.

Ao largo desses crimes comuns contra a ordem privada coexistem os chamados crimes econômicos em que a ordem econômica sofre agravo, muito mais graves porque percutem interesses sociais intensamente e com efeitos bem mais disseminados e profundos. Nesse tipo de delito os valores lesados não são exclusivamente os bens econômicos materiais em si mas seus reflexos na repartição ou usufruto das riquezas pelas diversas categorias de cidadãos, o que deveras incumbe essencialmente ao Estado garantir.

Acima desses, quer em importância quer em magnitude, encontram-se os crimes contra a coletividade ou sociais, até o presente muito pouco sancionados (por atraso legislativo ou desinteresse político), cujos objetivos tutelados constituem área francamente coletiva tais como a saúde, ecologia e salubridade públicas ou os crimes contra a ordem social e também aqueles contra a ordem econômica geral, além dos especificamente políticos (quando penalmente reprimidos) como tumultos, revoltas, insurreições ou revoluções.

É preciso anotar, por fim, para os efeitos do trabalho, os crimes de qualquer espécie praticados pelos próprios agentes públicos com abuso ou desvio de poder administrativo que thes confere o cargo ou a função pública, de vez que ferem diretamente interesses do Estado ao mesmo tempo em que produzem 
também lesão a particulares. Nesses casos, então, a relação entre a vítima e o Estado conta ainda com a participação essencial do agente público que, na hipótese, está a reforçar a participação daquele atribuindo-Ihe então, por outra razão bastante, a mesma responsabilidade patrimonial.

A esquematização do quadro acima, guardadas as devidas proporções e limitações ditadas e devidas pela necessidade de resumo, basta para a demonstração da curva de importância ligando os pequenos delitos contra o patrimônio individual aos grandes e significativos crimes contra a sociedade.

Esse ambiente serve como molde para a aferição dos graus da responsabilidade do Estado, quando nada pelo só fato da participação eminente dele na realidade social. Se eventualmente responder o Estado por danos que cidadãos sofram por ato criminoso de terceiros o índice da magnitude e imperatividade da reparação será guiado pela gradação dos objetos jurídicos tutelado na ordem referida.

\section{A JUSTIÇA}

Sob essa abrangente denominação (em homenagem ao sentido que o leigo normalmente dá ao termo) abriga-se todo o aparato repressor do Estado. Desde o ponto de vista penal, a perseguição ao delinqüente como agente criminoso é atividade específica e própria do Estado enquanto poder público.

Sem embargo, seja como retribuição social; como castigo (sentido estrito da pena); ou como busca de recuperação do infrator, a imposição da pena revela sempre e necessáriamente a auto afirmação do Estado e Ihe confere soberania indiscutível inerente à própria instituição ${ }^{1}$.

A relação necessária entre o Estado e o agente criminoso no processo de imposição da pena que é exclusiva atribuição e encargo daquele, como tal, é por isso também mais um fato primário a sugerir sua responsabilidade civil patrimonial perante terceiros.

Não se questiona modernamente que só ao Estado é permitido exercer o poder de punição sob qualquer de suas justificativas doutrinárias ou jurídicas. É função do Estado aplicar a pena

( 1) - v. no particular notável trabalho do professor argentino Juan Bustos Ramirez que desce fundo no tema dele extraindo interessantíssimas e (para nós latinoamericanos) atualizadissimas observações, "Bases críticas de un nuevo Derecho Penal, Temis, Bogotá, 1982, p. 142 e ss. 
ao delinqüente uma vez corrido o processo de apuração da sua responsabilidade penal e se ao particular é proibido fazer justiça pela mão própria, há obrigação do Estado de fazê-la pelos meios legais postos ao seu uso. Mais que poder tem o Estado nesses casos o dever de punir.

Quer dizer, em outros termos, surge para o grupo social, a coletividade e também ao cidadão o direito de exigir do Estado providências necessárias para a aplicação das penalidades previstas em lei. Tal pretensão todavia é exercida em juízo pelo órgão do ministério público que em nome daqueles age soberana e autonomamente. Isto é, a reparação (reabilitação) ou expiação (castigo) penal pelo criminoso é uma forma civil de responsabilização moral.

Bem disse Heleno Fragoso (Lições, Parte Geral, p. 147) que não há diferença ontológica entre o ilícito penal e ilícito civil. Neste último caso, pelo princípio geral aquele que lesar deve reparar. Naqueloutro - em que o objeto jurídico tutelado na maior parte das vezes é indisponível e imaterial - a reparação do dano "ex-delicto" pelo agente torna-se impraticável quando não inviável por diferentes razões alheias à vontade da vítima e mesmo do agente.

A dimensão patrimonial e civil da pena criminal está irrespondida pelo direito positivo.

\section{A RELAÇĀO DELINQÜENTE-VITTIMA E A INTERVENÇĀO DO ESTADO.}

Os doutrinadores e pesquisadores do direito penal vêm atualmente dedicando esforços e estudos cada vez mais significativos sobre a chamada dupla penal ou relação vítima delinqüente, no segmento disciplinar conhecido por vitimologia. De acordo com os propósitos da ciência em questão cuida-se de dar tratamento adequado também à vítima do evento e não apenas ao agente criminoso; pretende-se - o que embora notório não tem tido interesse legislativo - reexaminar e reavaliar a participação da vítima na ocorrência penal e no resultado criminoso.

Exemplo da importância dessa preocupação é a circunstância da absolvição do réu, em certos delitos importar em verdadeiro juízo depreciativo da vítima, sem, quanto a esta, observância do devido processo legal.

Em outros casos a vítima é co-participante do delito (como nos de trânsito; ou por provocação indireta na ostentação de ri- 
queza e jóias diante de público de reconhecida miséria; ou ainda, por uso de traje provocante ou sumário em ambiente propício à delinqüência de costumes, o que pode até excluir a sinceridade do dissenso da vítima.). ${ }^{2}$

Por essas circunstâncias a relação vítima/delinqüente não pode ser irrelevante para o direito e menos ainda para o Estado. Ao Estado de direito, com mais razão, em face da extensão do princípio da legalidade não pode ser estranha essa dupla aparência do crime. Pelo lado do agente e todas as teorias da pena ou pelo lado da vítima e as crescentes afirmações pela reparação total, vê-se que a análise dessa relação constitui matéria absolutamente obrigatória em qualquer tema que a contenha ou suponha.

Não é extraordinária, aliás, a previsão da reparação patrimonial diretamente pelo réu dos danos "ex-delicto" conforme consta da legislação civil (Código Civil, art. 159 c/c arts. 1518 e 1525).

Disso verte a idéia básica de que ao dano se impõe reparação, seja ele de responsabilidade do agente seja de responsabilidade residual de outrem. É possível, então, avançando-se um ponto as argumentações ordinárias - isto é, raciocinando-se pelo ângulo ou perspectiva da vítima - supor que não pode por princípio ficar irreparado o dano derivado de crime. Se o agente não tem capacidade patrimonial para repor o prejuízo da vítima ou seu equivalente, ou se o agente é desconhecido ou inidentificado, daí não se pode seguir logicamente a irreparabilidade definitiva do dito dano.

Há que se reconstruìr a teoria da reparação não mais pelo lado do agente mas pelo da vítima ou lesado, como, aliás, agudamente fizeram Celso Antonio Bandeira de Mello (Ato.. p. 143/ 144) com respeito à responsabilidade do Estado por ato próprio, Paul Duez (Traité . . , p. 432) ao abordar a teoria do risco administrativo como razão da responsabilidade do Estado, e F. P. Bénoit (Le Droit . . , p. 692) quando busca os fundamentos da responsabilidade do Estado.

Essa mesma perspectiva pode ser aproveitada para a cons-

( 2) -v. a excelente dissertação "A vítima em face do direito penal positivo", Eros Gradowski, preleção apresentada ao $\mathrm{I}^{\circ}$. Congresso Brasileiro de Criminologia em Londrina PR de 21 a 27 de outubro de 1973, com referência bibliográfica atualizada, que retoma o tema ventilado por Marwin Wolfgang em palestra também produzida nos anais do dito certame (este, indo ao ex tremo da vitimização coletiva do povo americano pelos erros e crimes cometidos pelo seu governo na Guerra do Vietnam). 
trução e elaboração de uma teoria da responsabilidade patrimonial do Estado por atos criminosos de terceiros.

As fronteiras, por sinal, são tão próximas e interligadas que Bénoit (op. loc. cit.) afirma a origem penal da responsabilidade civil, posto que primitivamente se procurava castigar fisicamente o culpado e autor do dano (exemplos frisantes são a Lei das Doze Tábuas; o Código Hamurabi; e os costumes tribais em geral). Hoje, pretende-se reparar o prejuízo da vítima, o que é, na expressão literal do genial tratadista, o "centro do problema", mesmo que por vêzes a chamada "culpa da vítima' possa ser valorizada para diluir a responsabilidade do Estado, como aparentemente faz Duez (Traité . . , p. 428) conferindo então significativa achega ao raciocínio ora exposto.

Assim, se a imprudente vítima de atropelamento ou a de queimaduras por excessivo e imprudente proximidade do local de disparo de fogos de artifício tem sobre si virtual julgamento indireto de sua conduta nos casos de responsabilidade civil, há semelhante e evidente interferência do Estado na relação penal vítima/delinqüente, quando absolve o réu atribuindo qualquer conduta exculpante da vítima.

Tal como a vítima também o Estado pode contribuir para o evento criminoso se não age oportunamente, sujeitando-se, por isso, à pretensão reparatória. Essa circunstância parece poder ser isolada porque constitui elemento autônomo, isto é, constitui atuação volitiva do Estado que aplica sanção e impõe pena.

Daí porque nos reflexos e efeitos patrimoniais da relação delinqüente/vítima acaba por se arrastar também o Estado e se - lesado por hipótese pode vir a ser responsabilizado conjuntamente pelo crime, por certo igualmente o Estado perante a própria vítima ou sujeito passivo direto.

O dano público, de que fala Magalhães Noronha (Curso . ..., 1983, p. 41) sempre existente no delito, quando permitido, tolerado ou não combatido resulta e induz responsabilidade do Estado.

A ressalva que é preciso ter sempre à mão é de que a despeito das idênticas raízes inexiste simetria absoluta entre a anatomia do ilícito penal e a do ilícito civil, de modo que o que é penalmente lícito nem sempre o é fora desses domínios (Magalhães Noronha, op. cit., p. 42). A responsabilidade por dano decorrente de crime nem sempre o é por causa do delito senão por causa civil subjacente ou imersa no fato criminoso ${ }^{3}$.

( 3) - A responsabilidade penal é pessoal e não passa da pessoa do réu, o que é princípio constitucional inconteste, conforme o disposto no art. 153 § $13 \mathrm{CF}$. 


\section{C) A QUESTĀO DA RESPONSABILIDADE.}

\section{O PRINCIPIO DO RESIDUO}

De acordo com o disposto no art. 39, VII, da Lei 7210, de 11 de Julho de 1984, (a nova lei de execução penal agora independente do Código de processo penal) é dever do condenado indenizar a vítima, conforme se tenha tornado certa tal obrigação por efeito do art. 91, I da Lei Penal (Código Penal, com a redação da Lei 7209/84 na Parte Geral) após sentença condenatória definitiva.

Reversamente, tem a vítima direito de pleitear reparação correspondente, consoante Ihe garantem os arts. 63 a 68 do Código de processo penal vigente, contra o agente criminoso. Nenhuma palavra, todavia, com relação à pretensão reparatória relativamente ao Estado.

Sem embargo disso, o espírito de modernidade, e mais do que isso, de justiça e efetividade do processo ${ }^{4}$, vêm construindo inexoravelmente a teoria da tutela dos interesses difusos ${ }^{5}$ e essa concepção avançada e crítica do próprio processo convencional pode fornecer a peça faltante na idealização de uma teoria da responsabilidade do Estado por danos "ex-delicto", mormente quando a criminalidade assume proporções endêmicas ou quando há no crime dimensões públicas incontroláveis.

Como veremos, os fundamentos da eventual responsabilidade do Estado por crimes pode derivar de conduta do próprio Estado, omissiva ou comissiva, por razão então de culpa ou falta de serviço ${ }^{6}$ ou por causa independente residual como emergência

( 4) - E preciso reler, nesse sentido, o trabalho de Barbosa Moreira (Estudos em Homenagem a J. Frederico Marques, 1982, p. 212 vários autores) e, com certa criatividade, ou tro do mesmo autor - "Tutela sancionatória e tutela preventiva" (Rev. Fac. de Dir. Curitiba, no. 19, ano 19, p. 117/126) que versa tema próximo pelo lado oposto, isto é, pelo da prevenção e não reparação.

( 5) - Excelente coletânea de trabalhos sobre a questão com bibliografia a jurisprudência encontra-se em livro com esse título sob a coordenação da prof. Ada Pelegrini Grinover, Max Limonad, 1984.

( 6) - "faute du service" - a despeito da tradução corrente significar a falta por culpa do serviço, é tecnicamente preferível, a meu ver, tê-la por falta (v. Ruy Cirne Lima, Princípios. . p. 201) ademais da noção de culpa para que seja possível conceber a falta de serviço na hipótese em que o Estado não organizou serviço que podia ou devia oferecer, não se cuidando então de mau funcionamento, não funcionamento ou funcionamento tardio. Simplesmente não havia serviço que devia ou podia existir. 
natural da inevitável estatização ${ }^{7}$.

Além disso, a sofisticação da criminalidade de largo espectro ou a vitimização coletiva correspondente ${ }^{8}$ exigem uma nova maneira de encarar tanto a questão da pena e sua execução, como a da reparação dos danos decorrentes do crime. $O$ processo judicial por sua vez passa a ter relevância política (Kazuo Watanabe, in Tutela . . . , p 97) que, a 'contrario sensu', já apontara Barbosa Moreira (Rev. Dir. . . p. 126) ao identificar e suspeitar pressupostos ideológicos na preferência do legislador pela tutela sancionatória em detrimento da preventiva.

\section{A NOVA MANEIRA DE PENSAR}

O discurso sobre a responsabilidade do Estado pelos atos ou fatos criminosos de terceiros conhecidos ou desconhecidos é um passo significativo nesse sentido e pode tornar sem dúvida mais nítido um dos contornos da função estatal que mais caro é ao cidadão: o em que se lhe garante a integridade do direito à vida, à segurança e à personalidade entre outros, ainda que para isso seja necessário modificar o modo de pensar de nossa civilização americana, que é um modo capitalista de pensar.

Na medida em que o nosso modo de pensar é uma decorrência do nosso modo de produção capitalista e, mais que isso, o modo de pensar necessário à reprodução do nosso capitalismo, leva-se obrigatoriamente para o conhecimento de senso comum e para o conhecimento científico as tensões do capitalismo expressas nas diferenciações ideológicas e de tendências dentro da mesma formação social", especialmente quando "subjuga quem não

( 7) - Tema aparentemente não versado mas que poderia desvendar nova face da questão está relacionado à existência e configuração de responsabilidade estatal nos regimes socialistas radicais ou comunistas porquanto, pelo menos em grande parte a reparação tem a sua razão de ser exclusivamente no fato da intocabilidade da propriedade que entretanto não tem idêntico valor naqueles regimes. V. ainda Canotilho, J J Gomes, O Problema da Responsabilidade do Estado por Actos lícitos. Almedina, Coimbra, 1974, p. 244; e Duez, Paul, Traité de Droit Administratif, p. 435, este justificando históricamente a teoria do risco como proteção da propriedade particular.

( 8) - v. nota 2. Daŕ a afirmação (Figueiredo Dias, Jorge de., Direito Proc. Penal, p. 572) "de que a defesa ... dos direitos civis da vítima tem de ser vista como uma tarefa pública. A Comunidade é co-responsável dos crimes que abalam os seus fundamentos".

( 9) - v. a notável 'Apresentação' do au tor no "Sobre o Modo Capitalista de Pensar", Hucitec, SP, 1982, de João de Souza Martins, da Universidade de São Paulo, especialmente páginas IX, X e XI. A tese desenvolvida, de metodologia e origem marxistas, sustenta que a maneira de pensar do cidadão é diretamente ditada pelo modo de produção da riqueza da sociedade em que vive e lhe condiciona inconscientemente os propósitos. 
é capitalista invertendo o sentido do mundo e dando uma direção conservadora e reacionária à ação que deveria construir a sociedade transformada ..."10

Ora, o conceito de modo de produção, como aquele de Estado, devem ser tomados a partir das contradições que eles organizam e não a partir da organização que eles manifestam ${ }^{11}$, tudo porque "I'Etat est, à cause des juristes, tou jours pensé comme 'au delà' du système social bourgeois: il faut aujourd'hui comprende qu'il est ce système ${ }^{\prime \prime 12}$. Sistema, diga-se, em que as relações de poder político são inerentes a todas as outras relações familiares, escolares, econômicas, culturais ${ }^{13}$.

Enfim, o Estado não é uma instituição 'na' sociedade; é ele ' $a$ ' forma da sociedade capitalista ${ }^{14}$. A concepção da responsabilidade patrimonial do Estado pelos danos às vítimas causados por crimes de terceiros por conseqüência não deve perder de vista a realidade sócio-política em que ocorrem, especialmente o ambiente de luta de classes onde preferencialmente o crime é uma entidade dela derivada e onde seguramente e paradoxalmente nãc é o maior fator de dano.

Em resumo, a relação de poder na sociedade capitalista engendra em grande parte o próprio crime, isto é, na linguagem indicada, o próprio Estado gera o crime $^{15}$.

\section{O RISCO SOCIAL}

Esse aparente desvio do centro da temática para questão lateral genérica permite contudo acomodar melhor a compreensão do que se propõe o presente trabalho. Em verdade, sem uma adequada situação dos postulados não é possível a exata inteligência da proposta deste trabalho, nem mesmo se lhe poderá perceber a lógica que devem garantir suas conclusões.

$\mathrm{O}$ que se procura está inteiramente abrangido pelo terreno algo inexplorado da responsabilidade objetiva do Estado.

\footnotetext{
(10) - Martins, João de Souza, op. cit. p.X.

(11) - Miaille, Michel. L'Etat du droit, P. U. Grenoble/Maspero, 1980 p. 19.

(12) - op. cit. p. 20.

(13) - op. cit. p. 21.

(14) - op. cit. p. 19;v. a propósito famoso tex to de Lenin sobre a extinção do Estado capitalista (Estado e a Revolução, capítulo I, n. 4.)

(15) - Para ampliação consultar Juarez Cirino dos Santos (A Criminologia Radical, Forense, Rio, 1981, p. 41) em especial com respeito ao conceito proletário de crime e ao conceito burguês de crime, que é sempre sintoma de "desorganização social. V. também "La Sociedad Criminógena" de Jean Pinatel, Aguilar, Madrid, 1979, capitulos 4 e 5, tradução para o espanhol de Luiz Rodrigues Ramos.
} 
Com efeito, tirante algumas hipóteses em que os danos sofridos por terceiros em razão de atos criminosos são decorrentes do liame necessário entre a conduta do Estado, do agente causador e o dano, e derivam da culpa administrativa (é o caso, por exemplo referido por Celso Antonio Bandeira de Mello, Ato... , p. 147, em que "agentes policiais relapsos assistiram a ocorrência inertes . ...") a responsabilidade do Estado de que se cogita não tem em princípio ligação material alguma com os fatos, senão numa perspectiva mais longa para a qual, justamente, são necessárias e preliminares as ponderações mensionadas anteriormente.

Trata-se de responsabilidade apenas pelo fato do Estado, razão porque seus fundamentos se apertam um pouco do carreiro convencional da teoria da responsabilidade predominantemente fundada na culpa. A igualdade e a legalidade se comportam bem como fundamentos que tais quando se defronta com a responsabilidade do Estado por ato ilícito (culpa) ou lícito (sacrifício ou dano anormal); não todavia no que respeita à responsabilidade do Estado por ato delituoso de terceiros (fora a hipótese culposa) porque o dano "ex delicto" não é anormal no sentido usual diante da atividade estatal, nem sacrifica a igualdade.

Há que se buscar outros fundamentos, já que é fundamento de toda responsabilidade o direito de que ela é a sanção (Bénoit, Le Droit. . . , p. 692). E quem dá a indicação mais inteligente deles é o notável Aguiar Dias em notas ao excelente "Responsabilidade Civil do Estado" de Amaro Cavalcanti (Borsoi, Rio, 1957, Tomo II, p. 708/ss.) ${ }^{16}$, arredando desde logo a "antiqualha da vetusta e inqualificável teoria civilista" tanto quanto a da irresponsabilidade verdadeira inadequada ao Estado intervencionista.

Referindo ocorrências de sedição, movimentos armados e mesmo guerras civis, com escólio em riquíssimos acórdãos do Supremo Tribunal Federal (ac do STF de 12.4 .43 e Ac. do STF de 2.2.43, entre outros), o autor foi recolhendo pela história judiciária um largo veio de inclinação jurisprudencial no sentido da responsabilidade objetiva do Estado, a qual, afinal, redundou no texto e doutrina da Constituição de 1946 . Ou seja, o nosso direito não só a tolera como a acolheu na estatura de preceito constitucional, dalí em diante expressamente.

Por isso, a teoria da responsabilidade objetiva do Estado, embora não como regra geral posto que por óbvio (e pelo Código

(16) - Também reproduzido em "Da Responsabilidade Civil", Forense Rio, 4a. edição, 1960, Volume II, p. 611/ss. 
Civil ou regras e princípios administrativos) a responsabilidade por culpa ainda o é, vem fundamentando numerosos casos de indenização pelo Poder público, sendo muitos deles sem relação de causa com a atuação do Estado.

Confiram-se os acontecimentos sociais e movimentos políticos que em maior ou menor grau destruiram ou danificaram patrimônio particular. Em tais hipóteses, e pendularmente ${ }^{i 7}$, o Supremo Tribunal Federal ora reconheceu a culpa na falta de atuação do Estado ora isentou-o de responsabilidade tendo-as por atos de guerra ou em virtude de ausência de culpa por força maior.

Nos casos em que admitiu a reparação estão incluidos alguns em que foi atribuida a responsabilidade ao Estado por culpa da inoperância do serviço público e outros em que admitiu o risco, talvez (como parece ter sido nos casos decorrentes da Revolução de 30) por reconhecimento da incapacidade de avaliação da culpa dos agentes da ordem ou pela absoluta impossibilidade de demonstração do nexo de causalidade ${ }^{18}$.

É verdade, no entanto, que deve o Estado permanecer atento, ou seja, o agente público tem a obrigação funcional de estar vigilante porque o exercício da competência não é um privilégio mas um dever (Duez, Traité, p. 424) e a inação mesmo não constituindo ilegalidade estrita pode gerar responsabilidade (Duez, op. loc. cit.).

Essa vigilância, segundo o tratadista, diz respeito entre outros aos presos, alienados, militares, condenados e alunos ou estudantes sob encargo do Estado ${ }^{19}$, justamente para prevenir o da-

(17) - V. os interessantes casos anotados pelo Ministro Filadelfo de Azevedo nos Acórdãos acima referidos relativos ao bombardeio criminoso de Manaus (1910) por oficiais revoltados ou ao bombardeio da Bahia em 1912, ou ainda aos danos às propriedades causados pelas lutas do Contestado, engendrando toda uma discussão sobre atos de guerra ou de preparação dela e força maior. Quanto a essa última aplicou-se o princípio para excluir a indenização

nos casos da revolução de 1924 e do levante do Forte de Copacabana em 1922. Em 1930, por danos causados pela revolução, virtualmente todas as decisões favoreceram os lesados, confirmando a tese objetiva. V. também Francisco Campos, Pareceres, p. 235.

(18) - V. Canotilho, op. cit. p. 242 e ss. em especial e comentário sobre os "Arrêts Lecomte et Daramy", p. 247/8 e sobre a teoria da faute lourde'única a autorizar então a responsabilidade do Estado nos acidentes com a polícia. A observação tem a sua razão de ser no fato da gradação da atuação policial na perseguição propor e revelar exclusão de culpa que no entanto não exclui a responsabilidade por risco como se vem admitindo modernamente.

(19) - Mesmo a falta pessoal "détâchable" pode por em relêvo a falta do serviço. V., a propósito, excelente parecer de Francisco Campos (Pareceres, Rio, 1934, p. $229 /$ ss.). 
no, mas Bénoit (Le Droit, p. 690, item 1248) vê aí uma "ilhota" de resistência à teoria da culpa afirmando (como Canotilho, v. nota supra) que há aí risco administrativo e abandono da responsabilidade subjetiva ${ }^{20}$.

0 mesmo se pode dizer com relação à vizinhança de locais ou atividades perigosos ${ }^{21}$ situações em que, a despeito da possível falta de serviço, tem sido adotada a responsabilidade pelo risco administrativo.

A questão da imputação necessária do dano à atuação de uma pessoa pública, como dado essencial à reparação anotada por exemplo por Rivero (Dir. Adm., p. 317), por essas razões não pode ser suposta ou imposta de maneira absoluta, mesmo que as hipóteses referidas pelo famoso professor da Universidade de Paris como de responsabilidade 'sans faute' e aquelas para 'além do risco' conservem sempre a exigência elementar da relação de causa com a atividade pública direta ou indiretamente ou com situações por esta criadas. É que Rivero (Dir. Adm., p. 327/8) duvida da evolução para a responsabilidade sem culpa como regra comum, pelo menos com base no Conselho de Estado da França, que sempre resistiu à idéia de socialização integral dos danos derivados da ação administrativa (Duez, op. cit., p. 434).

A inclinação geral da doutrina puxa para as vertentes da responsabilidade sem culpa como obra da expansão do Estado, mas não cede mais do que a exigência de uma mínima relação da causa com a ação do Estado. Isto é, na doutrina (no caso largamente induzida pela jurisprudência à falta de texto positivo) se exige sempre, pelo menos, uma relação de causa e efeito entre o dano indenizável e a ação do Estado ${ }^{22}$.

(20) - v. Rivero, Jean. Direito Administrativo, Almedina, Coimbra 1981, p. 349, no mesmo sentido com muita clareza e pertinência dividindo a hipótese de culpa (sempre possível) daquela de risco.

(21)-Além de Duez (Traité, p. 439/441),v. também Bénoit (Le Droit p. 681), Canotilho (O problema. . p. 252) e Celso Antonio (Ato .., p. 151). V. porém especificamente para o problema nuclear, Canotilho (O Problema ..p. 248/9) mostrando que já se menciona uma responsabilidade objetiva absoluta não só pela amplitude e dispersão dos danos possíveis como pelo caráter latente das lesões sofridas.

(22) - Deixa-se deliberadamente de dissertar sobre os princípios do sacrifício, igualdade, anormalidade e outros básicos na construção do conceito de dano indenizável sem todavia ignorá-los como fundantes da teoria da responsabilidade do Estado. E que para os limites deste trabalho e especialmente dentro do objeto do estudo, aparentemente, torna-se possível ter a ousadia de passar ao largo de tais questões. Embora não os utilizando diretamente deve-se deixar claro que sempre há que se tê-los em mira. 
$\mathrm{Na}$ perspectiva que se está adotando, o dano sofrido por terceiro em virtude de agente criminoso (que não é agente do Estado nem atua em seu nome), porque "ex-delicto" e pelas circunstâncias excepcionais que cercam toda a repressão ao crime, precisa ser suportado pelo Estado se não há culpa da vítima ${ }^{23}$ ou se o agente criminoso é insolvente ou desconhecido ${ }^{24}$.

Isto porque não se cuida por certo de proteger exclusivamente a propriedade privada da vítima (apenas um dos casos de crime é o contra o patrimônio) que é o fundamento sobre o qual se construiu toda a teoria vigente da responsabilidade e em particular aquela pelo risco administrativo (Duez, op. cit., p. 435). Se para a regra geral da responsabilidade do Estado ordinariamente se tem como índice a propriedade particular (e claramente a propriedade material) aqui e ali já se apontam outros valores ${ }^{25}$ a indicar nova concepção de responsabilidade quem sabe aderente ou decorrente de uma nova concepção de Estado.

Aliado a isso há que se passar a observar tais fatos pelo lado da vítima, pelo lado do sujeito que sofre o dano injustificável sob todos os modos de ver. $\vec{E}$ dizer, no que se relaciona à atividade pública sempre o interesse público está a justificar o dano a propriedade e o direito a tolerá-lo em face do bem comum. No crime, porém, nada em momento algum pode tolerar sua existência, tornando-se razoável por isso afirmar que a posição do Estado é diversa nessa hipótese e sua responsabilidade deve derivar então de outra 'ratio'.

Ora, a ordem pública é dever exclusivo do Estado para o que detém o poder, que se afirma na imposição da pena. Ao cidadão que cumpre todas as obrigações legais para a manutenção do aparelho e realização dos programas estatais não se pode imputar, então, em princípio, qualquer participação nos eventos criminosos senão como vítima 'sem culpa', totalmente passiva e indefesa já que não lhe corre sequer o direito de punir o criminoso.

Essa antinomia está a exigir a construçăo de uma justificativa da reparação pelo Estado, sem que isso importe em necessaria-

(23) - 'culpa de vítima' é o fato que exclui a causalidade entre a atividade oficial e o ato danoso (v. Aguiar Dias, J., em matéria publicada no Informativo Semanal 34 de 26.8.84 da ADV - Advocacia Dinâmica, do Centro de Estudos Superiores-COAD).

(24) - Francisco Campos nessa última hipótese vê caso de culpa da administração por falta de investigação exitosa (Pareceres p. 235/6).

(25) - Veja-se, por exemplo, a discussão do "pretium doloris" bem reportada por Jean Rivero, op. cit. p. 315/317. 
mente deduzir culpa ou risco administrativo, hipótese que permanecem quando for o caso.

Alguns exemplos, porventura, podem esclarecer e oferecer elementos indicativos da solução. 0 regime da responsabilidade por danos causados por tumultos nas comunas da França (v. Rivero, op. cit. p. 348) baseia-se na idéia de solidariedade dos habitantes pelas desordens cometidas no seu território. Isto é, não sendo possível o controle administrativo da desordem arcam com o prejuízo a Comuna e o Estado, sem prova alguma da culpa, quer dos agentes públicos quer dos desordeiros, porque há aí um princípio de risco social.

Canotilho (O Problema . . . , p. 263) refere o exemplo português em que se adotou claramente o conceito de risco social nas hipóteses de causação de danos durante tumultos, sem a perquirição da culpa ou da relação causal. ${ }^{26}$

Nos casos de fugas de presos ou alienados que venham a causar danos procurou-se ver responsabilidade do Estado por situação criada (cfr. C. A. Bandeira de Mello. O ato .., p. 151), dita de risco de vizinhança e de serviço especialmente perigoso (a jurisprudência tende por isso a tolerar-Ihe a reparação, afrouxando a crítica dos pressupostos).

Parece porém acertado o ponto de vista de Waline, referido por Canotilho (O Problema . . , p. 252), pela inadmissibilidade da limitação ao ressarcimento apenas aos habitantes ou moradores da vizinhança da prisão ou manicômio. De fato, não há como, sem discriminação injustificada, garantir reparação sómente aos vizinhos (como se os crimes praticados nas proximidades dos estabelecimentos penais tivessem nesses casos outra natureza). Ademais, nesse raciocínio, após a fuga o Estado seria responsável por atos delituosos praticados pelos evadidos, o que embora sustentável por outro fundamento não guardaria lógica com a doutrina esposada oficialmente.

$\mathrm{Na}$ verdade, os danos praticados pelos prêsos fugidos têm a mesma natureza daqueles causados pelos criminosos primários em liberdade e se naqueles casos enxerga-se razão de reparabilidade por perigo, dever de vigilância ou mesmo por risco social, também com relação a estes últimos há que se reconhecer ressar-

(26) - Para a jurisprudência mais antiga consultar Amaro Cavalcanti (Responsabilidade Civil do Estado, p. 635/639 e 733) e C. A. Bandeira de Mello (Ato. . , p. 171 , sem referência) para as mais modernas.

V. também Ruy Cirne Lima (Princípios ..., p. 204) que refere o caso da Revolução riograndense de 1923 em que a responsabilidade pelos danos sofridos pelos particulares foi assumida pela União. 
cibilidade, pelo menos por analogia quando não por eqüidade ou, aí sim, igualdade ${ }^{27}$.

Essas situações entre outras mais que poderiam ser eventualmente descritas traduzem a certeza de que além da culpa e do risco tem o Estado responsabilidade perante danos de terceiros causados por crimes não ligados à atividade oficial, nem mesmo indiretamente.

Importante referência nesse sentido foi trazida por Aguiar Dias (também reproduzida em Notas ao belo trabalho de Amaro Cavalcanti, Responsabilidade Civil do Estado, Tomo II, p. 721 e ss.) na obra da Responsabilidade Civil (Tomo II, p. 625). Diz o mestre, verbis:

"Avançar até à composição dos danos resultantes da atividade criminosa de particulares é, por enquanto, prematuro, embora seja lícito prever a evolução, lògicamente endereçada a esse ponto, da responsabilidade civil do Estado. Nisto fazem crer as conquistas, cada vez mais animadoras, da idéia de solidariedade, tão profundamente impressa no campo da assistência social ....'" (grifei)

A lógica apontada há mais de um quarto de século pelo notável jurista é a que nos propomos demonstrar para a conclusão que parece evidente ${ }^{28}$.

O governo escolhido pelo povo recebe mandato deste para administrar como encargo do Estado a consecução da paz social e há o direito do cidadão à incolumidade (v. Aguiar Dias, op. cit. p. 626). Não prevalecem portanto afirmações como a de Celso Antonio (Ato . . , p. 147) de que o Estado não pode ser erigido em segurador universal. Essa objeção foi reproduzida por Pedro

(27) - As referências a igualdade, sacrifício a anormaliade que daqui por diante se fizerem devem guardar a necessária relação com a 'ratio' da teoria da responsabilidade ora esboçada.

(28) - Edgard de Moura Bittencourt (Vítima, e.u.d., 2a. ed., 1978, SP, p. 115/122) comenta providências e iniciativas pelas quais o direito francês (há menção à lei de 31.12 .51 ) já contém disposições no sentido de garantir à vítima a indenização nos casos de lesão corporal causada por acidente de trânsito em que o responsável seja desconhecido ou insolvável. Embora a entidade que indenize não seja o Estado mas um fundo de garantia revela-se a importância do fenômeno, desde o ponto de vista e perspectiva da vítima. Aliás, no prefácio da edição consultada, M. Claude Roland Souchet (v. p. 20) refere a lei francêsa de 3.1.77 que garante indenização a certas vítimas de danos corporais resultantes de infração intencional. Para Figueiredo Dias (op. cit. p. 574), aceita a idéia da co-responsabilidade do Estado importa estabelecer um fundo público especial que assegure indenização. 
Lessa (citado por Aguiar Dias em notas a Amaro Cavalcanti, p. 727) para destruí-la com vantagem inconteste. Com efeito, o grande ministro observou que "a suceder tal coisa, o fato só revelaria o mau funcionamento do serviço público e a desordem da administração" que de modo nenhum podem ser atribuídos ou suportados pelo cidadão simplesmente.

Por força dessas ponderações é preciso concordar com Canotilho (O Problema. . , p. 258) para quem por via do apelo ou invocação do princípio da solidariedade social, da igualdade perante encargos públicos e até mesmo do conceito de 'perigo geral' chega-se ao "princípio da socialidade" (ou 'Sozialstaatprinzip'). Semelhante construção referida como relacionada à responsabilidade do Estado por danos de guerra, calha à perfeição como fundamento capaz de justificar também a reparação dos danos causados por criminosos a particulares, um pouco como se fossem 'terroristas', elementos em rebelião ou em tumulto, para cujos casos já se tem, sem grande resistência, aplicado o mesmo princípio, ou como se vivessemos em verdadeiro estado de guerra' com a criminalidade crescente.

O princípio da socialidade deduz uma modalidade de risco social que

“impõe certamente ao Estado e aos outros detentores do poder dos poderes públicos a conformação da vida social no sentido de uma justiça material, e o princípio da igualdade exigirá não só a proibição de encargos desiguais mas ainda a distribuição de iguais prestações e benefícios aos cidadãos colocados nas mesmas situações de fato' ${ }^{\prime 29}$.

Como a responsabilidade é sanção para o direito violado segue-se que lesada criminosamente a incolumidade do cidadão responderá o Estado patrimonialmente.

\section{D) CONCLUSĀO}

Cosendo os postulados dissertados pode-se concluir defensavelmente que o Estado há de responder patrimonialmente em face de danos ou lesões sofridos por cidadãos, produzidos por atos criminosos de terceiros, originaria ou alternativamente, em vista do princípio da socialidade que é o ponto extremo da teoria

(29) - Canotilho, J. J. Gomes, op. cit., p. 258. 
do risco social e pela qual se garante àquele a incolumidade $e$ integralidade de seus direitos contemplados na organização do Estado.

Decorrência disso, na concretização dessa pretensão reparatória, limitada apenas pelas circunstâncias do delito e extensão do dano conversível em indenização, cabe à jurisdição a decretação da responsabilidade e a declaração de seu valor por provocação e exercício do direito de ação contra o Estado (federado, no caso brasileiro) que é quem tem o encargo da ordem pública ${ }^{30}$ e o dever de garantir a incolumidade do cidadão.

Ressalva-se a responsabilidade do Estado ( a União), por certo, nos casos em que sob a 'ordem pública' alojarem-se hipóteses de crime contra a "ordem política" ou "democrática", também lesivos ao cidadão e não diretamente causados pelo Estado ou seu agente.

(30) - Para completo exame do conceito de 'ordem pública' e sua dimensão, por exemplo,consultar Silva, José Afonso da (A aplicabilidade das Normas Constitu cionais, RT, SP, 1982, 2a . edição, p. 96/99, especialmente do ponto de vista constitucional que aqui nos interessa. 


\section{BIBLIOGRAFIA}

BANDEIRA DE MELLO, Celso Antonio. Ato Administrativo e Direito dos Administrados, RT, SP, 1981.

BARBOSA MOREIRA, José Carlos. Tutela sancionatória e Tutela preventiva, in Revista da Faculdade de Direito, Curitiba no. 19, Ano $19(1978,1979,1980)$.

BENOIT, Francis-Paul. Le Droit Administratif Français, Dalloz, 1968, (cinquième partie).

BITTENCOURT, Edgard de Moura. Vítima, E.U.D. - Edição Universitária de Direito, 2a. edição, SP, 1978.

CAMPOS, Francisco. Pareceres, Rio, Tipografia do Jornal do Comércio, 1934.

CANOTILHO, José Joaquim Gomes. O Problema da Responsabilidade do Estado por Actos Lícitos, Almedina, Coimbra, 1974.

CAVALCANTI, Amaro. Responsabilidade Civil do Estado, Borsoi, nova edição atualizada e com notas de José Aguiar Dias, Rio, 1957, 2 Volumes.

CIRINO DOS SANTOS, Juarez. A Criminologia Radical, Forense, Rio 1981.

CIRNE LIMA, Ruy. Princípios de Direito Administrativo, Sulina, 4a. edição, Porto Alegre, 1964.

DIAS, José de Aguiar. Da Responsabilidade Civil, Forense, 4a . edição, Rio, 2 Volumes.

DUEZ, Paul e Debeyre, Guy. Traité de Droit Administratif, Dalloz, 1952.

FRAGOSO, Heleno Claudio. Lições de Direito Penal, Forense, 5a. edição, Rio, 1983 (Parte Geral).

GRADOWSKI, Eros. A vítima em face do direito penal positivo, Anais do I Congresso Brasileiro de Criminologia, Londrina PR, 1973.

GRINOVER, Ada Pellegrini e outros. A Tutela dos Interesses Difusos, Max Limonad, 1 a. edição, SP, 1984.

LENIN, Vladimir Ilich. O Estado e a Revolução, Edições em língua estrangeira, Moscou, s/d.

MARTINS, José de Souza. Sobre o modo capitalista de pensar, Hucitec, 3a. edição, São Paulo, 1982.

MIAILLE, Michel. L'Etat du Droit, Presses Universitaires de Grenoble/Maspero, Grenoble, 1980.

NORONHA, Edgard Magalhães. Curso de Direito Processual Penal, Saraiva, 1983, $15^{a}$. edição, São Paulo.

PINATEL, Jean. La Sociedad Criminogena, Aguilar, Madrid, 1979, (tradução de Luiz Rodrigues Ramos).

RIVERO, Jean. Direito Administrativo, Almedina, Coimbra, 1981.

SILVA, José Afonso da. Aplicabilidade das Normas Constitucionais, 2a. edição RT, SP, 1982.

RAMIREZ, Juan Bustos. Bases Críticas de un Nuevo Derecho Penal, Editorial Temis, Bogotá, 1982.

FIGUEIREDO DIAS, Jorge de.Direito Processual Penal, Coimbra Editora, Limitada, Primeiro Volume, Coimbra, 1974. 